\title{
EARLY FLUID ADMINISTRATION IN EXTREMELY PRETERM NEWBORNS (WITH BIRTH BODY MASS $\leq 1200 G$ ) AND ITS RELATIONSHIP WITH THE LEVEL OF NT-PROBNP AND PDA
}

\author{
T. Talar ${ }^{1}$, E. Gulczyńska ${ }^{1}$, B. Cyranowicz ${ }^{1}$, M. Kęsiak ${ }^{1}$, E. Świątkowska ${ }^{2}$ \\ ${ }^{1}$ Department of Neonatology, ${ }^{2}$ Laboratory, Polish Mother's Memorial Hospital Research Institute, Lodz, \\ Poland
}

Background: Patent arterial duct [PDA] is a common problem in extremely preterm babies. Its hemodynamic significance is considered to be partly dependent on fluid management, especially in extremely low birth weight preterms [ELBW]. Some authors propose N-terminal pro Brain Natriuretic Peptide[NT-proBNP] as an indicator of significance of PDA.

The aim of our study is to check the relationship between early intravenous fluid intake, the level of NTproBNP and PDA diameter.

Methods: Between 2009 and 2011, twenty ELBW preterms were included for the study. The main inclusion criteria were: birth mass $\leq 1200 \mathrm{~g}$, birth age $\leq 28$ weeks. Blood sample for NT-proBNP measurement just after delivery and in the second day of life were collected. An echocardiography was performed simultaneously with the second sample for NT-proBNP. The diameter of arterial duct and, the LA/Ao ratio were measured. Total fluid administration [TFA] until the moment of the second NT-proBNP collection was calculated and expressed as $\mathrm{ml} / \mathrm{kg} / \mathrm{h}$. The results were compared and analyzed. Five newborns were excluded from the analysis.

Results: Median diameter of PDA, La/Ao ratio, TFA, NT-proBNP level in three groups of patients are presented below:

\begin{tabular}{|c|c|c|c|}
\hline & $\begin{array}{c}\text { NO PDA } \mathrm{n}=4 \\
\text { median/range }\end{array}$ & $\begin{array}{c}\text { PDA NOT } \\
\text { SIGNIFICANT } \mathrm{n}=5 \\
\text { median/range }\end{array}$ & $\begin{array}{c}\text { PDA SIGNIFICANT n=6 } \\
\text { median/range }\end{array}$ \\
\hline PDA $[\mathbf{m m}]$ & 0 & $1,18(0,8-1,5)$ & $2,03(1,7-2,2)$ \\
\hline TFA $[\mathbf{m l} / \mathbf{k g} / \mathbf{h}]$ & $4,49(4,2-5,2)$ & $4,8(3,6-6,3)$ & $3,87(3,4-4,76)$ \\
\hline \hline NT-proBNP[pg/ml] & $10690(5244-22783)$ & $4823(4190-7582)$ & $19500(12265-35000)$ \\
\hline
\end{tabular}

[Table 1]

Conclusions: NT-proBNP is a useful tool for indication of hemodynamic significance of PDA. Intravenous fluid administrated according to patient requirements, influences neither the diameter of PDA nor NTproBNP level. 